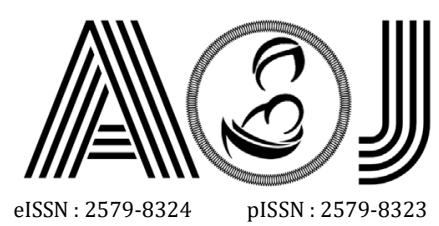

eISSN : 2579-8324
pISSN : 2579-8323

\title{
RESEARCH
}

\section{Relationship between Husband's Support, Knowledge Level, and Motivation with IVA Examination Behavior in Women of Childbearing ge in Padang City}

Intan Firmana Putri ${ }^{1}$, Ferdinal Ferry ${ }^{2}$, Hafni Bachtiar ${ }^{3}$

Affiliation author: 1. Obstetrics and Gynecology, Faculty of Medicine, Andalas University, Dr. M. Djamil Central General Hospital Padang; 2. Sub Division of Social Obstetrics and Gynecology, Obstetrics and Gynecology Department, Faculty of Medicine, Andalas University, Dr. M. Djamil Central General Hospital Padang; 3. Public Health Department, Faculty of Medicine, Andalas University Padang

Correspondence to: Intan Firmana Putri, email: intanfirmanaputri@gmail.com, Hp:08111031411

\section{Abstract}

Background: Cancer is the second leading cause of death in the world. Cervical cancer is in the $9^{\text {th }}$ position out of 35 types of cancer causing the most deaths in the world. Cervical cancer is the second highest type of cancer after breast cancer in women, which affects more than 1.4 million women worldwide. Every year more than 460,000 cervical cancer incidents occur and about 231,000 women die from the disease.

Objectives: This study aims to determine the relationship between husband's support, level of knowledge and motivation, with the behavior of IVA examination in fertile aged women in the city of Padang.

Methods: This research is an analytic observational study with cross-sectional comparative study approach that looks at the relationship between knowledge, motivation, and husband's support with IVA examination behavior in women of childbearing age.

Results: The percentage who did not perform IVA examination was higher among respondents with low motivation compared to those with high motivation, namely $54.7 \%$ versus $45 \%$. Statistically this difference was not significant ( $p>0.05$ ). The number of respondents who did not perform IVA examinations was higher for respondents with less husband's support, namely 32 respondents (42.1\%) and more than half of respondents who did IVA examinations, namely 44 respondents (57.9\%) who received less support from their husbands. Statistically this difference was significant $(p<0.05)$.

Conclusion: There is a relationship between the level of knowledge and the behavior of the IVA examination, there is no relationship between motivation and the behavior of the IVA examination and there is a relationship between the level of knowledge and the behavior of the IVA examination.

Keywords: IVA, women of childbearing age, education

\section{INTRODUCTION}

Cancer is the second leading cause of death in the world. Cervical cancer is in the $9^{\text {th }}$ position out of 35 types of cancer, causing the most deaths in the world. Cervical cancer is the second highest type of cancer after breast cancer in women, which affects over 1.4 million women 


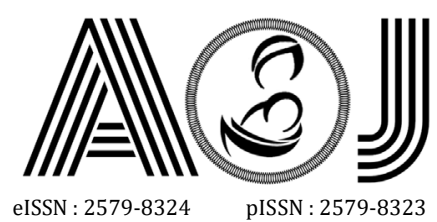

eISSN : 2579-8324
pISSN : 2579-8323

worldwide. Each year over 460,000 cervical cancer incidents occur and about 231,000 women die from the disease.

Data from the ministry of health shows Indonesia have 90-100 cases of cervical cancer per 100,000 population per year, and the spread is accumulated in Java and Bali. ${ }^{2}$ Cervical cancer is a malignant tumor that grows in the cervix or cervical cancer originates from $90 \%$ squamous cells which lines the cervix and the remaining $10 \%$ comes from mucus-secreting gland cells in the cervical canal leading into the uterus. ${ }^{3}$ Cervical cancer is directly related to previous infection of one or more Human Papilloma Viruses (HPV). ${ }^{4}$

Several methods of screening and early detection of cervical cancer are known, include: the pap smear test, IVA, IVA examination with ginescopy, colposcopy, cervixography, thin prep and HPV test. ${ }^{5}$ However, under the conditions in developing countries Indonesia include is to use the IVA method, because the technique is easy / simple, low cost / cheap and the level of sensitivity is high, fast and accurate enough to find abnormalities at the stage of cell disorders (dysplasia) or before pre-cancer. For this reason, an IVA test is recommended for all women aged 30 to 50 years and women who have had sexual intercourse. ${ }^{4}$

Family support plays a very important role in increasing the interest or willingness of women to carry out early detection tests using the IVA method. Families can be a powerful motivator if they always take the time to accompany or escort to health services and remind mothers to do IVA checks. Linadi's research (2013) also states that there is a relationship between husband's support and WUS participation behavior in early detection of cervical cancer. The intended support from the husband can be in the form of providing information about cervical cancer or IVA examinations or in the form of a positive response if the wife invites a discussion about women's health problems such as cervical cancer and IVA examinations. Besides husband's support, education and knowledge also influence the low coverage of early detection of precancerous lesions. According to research conducted by Sumartini (2013) in Linadi (2013), the low coverage of early detection is one of the reasons for the growing development of cervical cancer. ${ }^{6}$

Based on previously described, it needs similar research to study the effect of husband's support, level of knowledge and motivation with early detection of cervical cancer in several subs-districts in Padang City, with relatively low IVA examination coverage. This study is almost the same as the previous research, the difference is that this research was conducted in Padang city which has differences in social life compared to other areas, still influenced by cultural backgrounds which still consider examining the pubic area is taboo. 


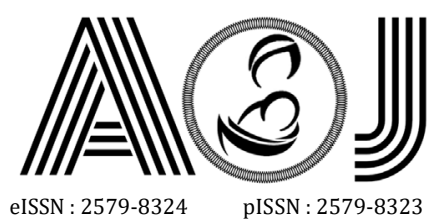

eISSN : 2579-8324

pISSN : 2579-8323

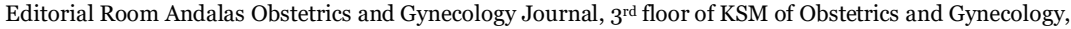

RSUP DR. M. Djamil Padang, Jl. Perintis Kemerdekaan Padang, Sumatera Barat 25127

Website:

http://jurnalobgin.fk.unand.ac.id/index.php/JOE

\section{PURPOSE}

This study aims to determine the relationship between husband's support, level of knowledge and motivation, with the behavior of IVA examination in Woman of childbearing age in Padang City.

\section{METHOD}

This research is an observational analytic study with a cross-sectional comparative study approach that looks at the relationship between knowledge, motivation, and support of husbands with IVA examination behavior in women of childbearing age. The study was conducted at the Padang City Health Center from January to February 2020. All population of this study was women of childbearing age in Padang city. Samples 62 people each group. Samples were women who came to the Health Center in Padang City and women who had performed IVA examinations based on data at the Health Center that met the inclusion criteria.

Inclusion criteria

1. Willing to be research respondents

2. Husband and wife live together

The instrument in this study was a questionnaire, used to assess individual characteristics, knowledge of IVA, motivation, and support provided by husbands to wives.

\section{RESULT}

Table 1 Respondent Characteristics

\begin{tabular}{lcc}
\hline \multicolumn{1}{c}{ Characteristics } & $\begin{array}{c}\text { Do not perform IVA } \\
\text { Mean } \pm \text { SD }\end{array}$ & $\begin{array}{c}\text { Perform IVA } \\
\text { Mean } \pm \text { SD }\end{array}$ \\
\hline Age & $\begin{array}{c}32,1 \pm 6,1 \\
\mathbf{f ( \% )}\end{array}$ & $34,4 \pm 8,7$ \\
Education & & $(\%)$ \\
a. Elementary & $1(50,0 \%)$ & $1(50,0 \%)$ \\
b. Junior High & $5(41,7 \%)$ & $7(58,3 \%)$ \\
c. High school & $43(53,8 \%)$ & $37(46,3 \%)$ \\
d. Diploma/Bachelor degree & $13(43,3 \%)$ & $17(56,7 \%)$ \\
Occupation & & \\
a. House wives & $47(57,3 \%)$ & $35(42,7 \%)$ \\
b. Civil Servant & $6(46,2 \%)$ & $7(53,8 \%)$ \\
c. Self-worker & $3(25,0 \%)$ & $9(75,0 \%)$ \\
d. Merchant/Enterpreneur & $6(35,3 \%)$ & $11(64,7 \%)$ \\
\hline
\end{tabular}




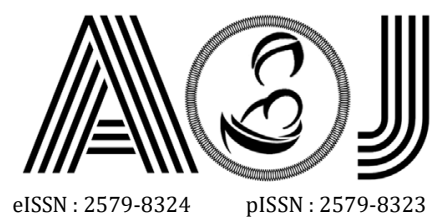

eISSN : 2579-832
pISSN : 2579-8323

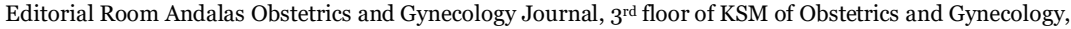

RSUP DR. M. Djamil Padang, Jl. Perintis Kemerdekaan Padang, Sumatera Barat 25127

Based on Table 1, it is known that the mean age who did not undergo IVA examination was $32.1 \pm 6.1$ years, while in the group that did IVA examination, it was $34.4 \pm 8.7$ years. Most of the respondents were $43(53.8 \%)$ in the group who did not undergo IVA examination and $37(46.3 \%)$ in the group who did the IVA examination with high school education level. More than half of the respondents, namely $47(57.3 \%)$ in the group that did not undergo IVA examinations and $35(42.7 \%)$ in the group that did the IVA examination were housewives.

Table 2 Relationship between Knowledge Level and IVA Examination.

\begin{tabular}{|c|c|c|c|c|c|c|c|}
\hline \multirow{3}{*}{$\begin{array}{c}\text { Knowledge } \\
\text { Level }\end{array}$} & \multicolumn{4}{|c|}{ IVA Examination } & & & \multirow{3}{*}{ p value } \\
\hline & \multicolumn{2}{|c|}{ No } & \multicolumn{2}{|c|}{ Yes } & \multicolumn{2}{|c|}{ Total } & \\
\hline & $f$ & $\%$ & $f$ & $\%$ & $f$ & $\%$ & \\
\hline Low & 34 & 61,8 & 21 & 38,2 & 55 & 100 & 0,03 \\
\hline High & 28 & 40,6 & 41 & 59,4 & 69 & 100 & \\
\hline Total & 62 & 50 & 62 & 50 & 124 & 100 & \\
\hline
\end{tabular}

Based on Table 2, the percentage who did not perform IVA examinations was higher in respondents with low knowledge than those with high knowledge, i.e. $61.8 \%$ versus $40.6 \%$. Statistically this difference was significant $(p<0.05)$.

Table 3 Relationship between individual motivation and IVA examination.

\begin{tabular}{|c|c|c|c|c|c|c|c|}
\hline \multirow{3}{*}{$\begin{array}{l}\text { Individual } \\
\text { Motivation }\end{array}$} & \multicolumn{4}{|c|}{ IVA Examination } & \multirow{2}{*}{\multicolumn{2}{|c|}{ Total }} & \multirow{3}{*}{$p$ value } \\
\hline & \multicolumn{2}{|c|}{ No } & \multicolumn{2}{|c|}{ Yes } & & & \\
\hline & $f$ & $\%$ & $f$ & $\%$ & $f$ & $\%$ & \\
\hline Low & 35 & 54,7 & 29 & 45,3 & 64 & 100 & 0,37 \\
\hline High & 27 & 45,0 & 33 & 55,0 & 60 & 100 & \\
\hline Total & 62 & 50 & 62 & 50 & 124 & 100 & \\
\hline
\end{tabular}

Based on Table 3, it is known that the percentage respondents who did not perform IVA examinations higher in respondents with low motivation compared to those who had high motivation, $54.7 \%$ versus $45 \%$. This difference was not statistically significant ( $p>0.05)$.

Table 4 Husband's Support Relationship with IVA Examination.

\begin{tabular}{|c|c|c|c|c|c|c|c|}
\hline \multirow{3}{*}{ Husband's Support } & \multicolumn{4}{|c|}{ IVA Examination } & \multirow{2}{*}{\multicolumn{2}{|c|}{ Total }} & \multirow{3}{*}{$p$ value } \\
\hline & \multicolumn{2}{|c|}{ No } & \multicolumn{2}{|c|}{ Yes } & & & \\
\hline & $f$ & $\%$ & $f$ & $\%$ & $f$ & $\%$ & \\
\hline Less & 32 & 42,1 & 44 & 57,9 & 76 & 100 & 0,04 \\
\hline Good & 30 & 62,5 & 18 & 37,5 & 48 & 100 & \\
\hline Total & 62 & 50 & 62 & 50 & 124 & 100 & \\
\hline
\end{tabular}

Based on Table 4, the number of respondents who did not perform IVA examinations was higher in respondents with less husband's support, 32 respondents $(42.1 \%)$ and the 


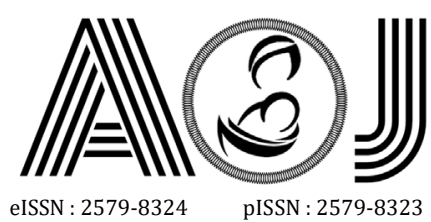

eISSN : 2579-8324
pISSN : 2579-8323

Editorial Room Andalas Obstetrics and Gynecology Journal, $3^{\text {rd }}$ floor of KSM of Obstetrics and Gynecology, RSUP DR. M. Djamil Padang, Jl. Perintis Kemerdekaan Padang, Sumatera Barat 25127

Website:

http://jurnalobgin.fk.unand.ac.id/index.php/JOE

respondents who did IVA examinations were more than half, 44 respondents $(57.9 \%)$ had less husband's support. Statistically this difference was significant $(p<0.05)$.

\section{DISCUSSION}

Based on the results, the mean age of respondents who did not perform IVA examination 32.1 \pm 6.1 years. 43 out of 62 respondents who did not perform IVA examinations had a history of high school education and 47 respondents were housewives. According to WHO, women aged 40-45 years have a high risk for cervical cancer. Women in the premenopausal age range should do an examination to detect cervical cancer early, in the form of an IVA examination or a pap smear.

The results of this study show that the level of knowledge can influence the behavior of the IVA examination. Over half of the respondents who did not perform IVA examinations had a low level of knowledge regarding cervical cancer and IVA examinations. The results of this study are in line with research by Linadi (2013) where there is a relationship between the level of knowledge and participation in the pap smear. ${ }^{6} 69 \%$ of respondents did not know that over 35 years of age are at risk of developing cervical cancer. The results of the study also showed that $69 \%$ of respondents thought IVA examinations could only be done by obstetricians and gynecologists. This situation shows that the lack of public knowledge due to the lack of information they get about cervical cancer and efforts to prevent it. Therefore, more active health promotion efforts are needed, especially for health centers as the first level health facilities that provide early detection services for cervical cancer through IVA examinations.

From the results, we know that individual motivation does not affect the behavior of the IVA examination. In contrast with research conducted by Indah (2015) where maternal motivation is related to IVA examination behavior. ${ }^{7}$ Likewise, with research conducted by Sari (2017) where there is a relationship between motivation for early detection of cervical cancer and the act of carrying out a pap smear. Individuals' motivation and attitudes towards screening efforts can influence their decision to perform the screening or not. Motivation has a function, specifically encouraging someone to make a healthy effort, in this case an IVA examination. Motivation can determine the direction of the action to achieve goals. The results indicate that there is no relationship between motivation and IVA examination. Internal and external factors can influence a person's motivation.

The results of this study indicate that husband's support is associated with IVA examination behavior. More than half of the respondents who did not undergo IVA examinations received less support from their husbands. However, in the group that underwent IVA examinations, more than half of the respondents did not get support from their husbands. This shows that most of the respondents who performed IVA examinations of their own volition. The results of this study are in line with research conducted by Linadi 


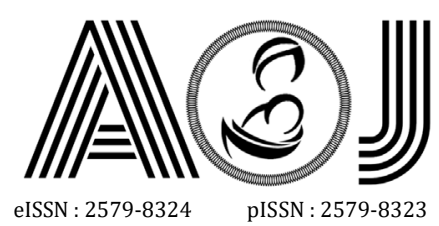

eISSN : 2579-8324

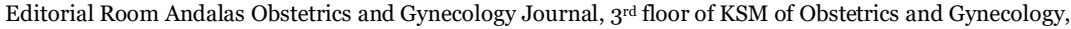

RSUP DR. M. Djamil Padang, Jl. Perintis Kemerdekaan Padang, Sumatera Barat 25127

Website:

http://jurnalobgin.fk.unand.ac.id/index.php/JOE

(2013) where there is a relationship between husband's support and participation in the pap smear. Most of the respondents who did not do the pap smear did not get support from their husbands. ${ }^{6}$

\section{CONCLUSION}

There is a relationship between the level of knowledge and the behavior of the IVA examination, there is no relationship between motivation and behavior in the alVA examination and there is a relationship between the level of knowledge and behavior in the IVA examination.

\section{REFERENCES}

1. Cancer Fact Sheets [Internet]. IARC, WHO. 2018. Available from: https://gco.iarc.fr/today/fact-sheets-cancers\#.

2. Rasjidi la. Vaksin Human Papilloma Virus dan Eradikasi Kanker Mulut Rahim. Malang: Sagung Seto; 2009.

3. Nugroho T. Masalah Kesehatan Reproduksi Wanita. Yogyakarta: Nuha Medika; 2014.

4. Kemenkes RI. Panduan Nasional Gerakan Pencegahan dan Deteksi Dini Kanker Leher Rahim dan Kanker Payudara Jakartaa: Kemenkes Rl; 2015.

5. Wilgin, Christin. Skrining Kanker Serviks dengan IVA dan Model Aplikasi di Lapangan. Jakarta: FKUI; 2011.

6. Linadi KE. Dukungan Suami Mendorong Keikutsertaan Pap Smear Pasangan Usia Subur di Perumahan Pucang Gading Semarang. Jurnal Kesehatan Reproduksi. 2013;4(2):61-71.

7. Kurniawati la. Pengaruh pengetahuan, motivasi, dan dukungan suami terhadap perilaku pemeriksaan IVA pada kelompok wanita usia subur di Puskesmas Kedungrejo [Tesis]. Surakarta: Universitas Sebelas Maret; 2015.

8. Sari AN. Hubungan motivasi deteksi dini kanker serviks dengan tindakan pap smear pada wanita usia subur di wilayah Gonilana. IJMS. 2017;4(2):189-95. 